\title{
THE IMPORTANCE OF UNDERSTANDING THE HYDROGEOLOGY AND GEOCHEMISTRY OF KARST TERRAINS FOR SAFELY SITING DAMS
}

\author{
Abolfazl Rezaei ${ }^{1,2}$, Hajt Karimi ${ }^{3} *$, Hongbin Zhan ${ }^{4}$
}

\begin{abstract}
Dam site selection in karst regions is an extremely important issue in terms of dam safety and environmental impact. Groundwater in a karst aquifer near a selected dam site is deemed to be impacted greatly by the dam. This study uses the Kangir Reservoir of Iran as an example to illustrate the interrelationships of karst-groundwater condition, lithology of the dam reservoir, future climate changes, and overexploitation of water resources in the area. This study conducted a comprehensive analysis of water balance, groundwater flow, hydrochemistry, characteristics of geologic formations with respect to the quantity and quality of water, distribution of karst and evaporative formations in the catchment, and tectonic setting to highlight the importance of hydrogeological conditions on the water quality and quantity of the Kangir Reservoir. The main findings include, first, a major part of the highland karst aquifer in the Asmari Formation within the dam catchment does not drain into the dam reservoir. Instead, it leaks into the downstream Siahgel Region of the dam mainly along the Zarneh-Siahgel fault zone through the karstic Asmari Formation. Second, selecting the dam site on evaporative Gachsaran Formation causes degradation of water quality in the reservoir. The results of this study demonstrate that considering karst hydrogeological conditions is indispensable for dam site selection from the point of view of groundwater quantity and quality impacted by the dam.
\end{abstract}

\section{INTRODUCTION}

Water storage is important for economic and social development in nearly every country around the world. Taking Iran as an example, where precipitation occurs in the autumn and winter while farmers need water for irrigation in the spring and summer, groundwater is usually the primary source to meet the agricultural needs for crop irrigation. To supplement the water supply, surface water reservoirs are constructed to collect and store water during the non-irrigated season of high rainfall and river flows. Most parts of Iran have low precipitation and most streams in Iran are ephemeral, thus, groundwater plays an indispensable role for supplying water to the reservoirs, often through base flow.

In the most recent two decades, climate changes such as drought together with overexploitation of surface water and groundwater have reduced river discharge or even dried up most rivers in Iran (Motagh et al., 2008; Lehane, 2014). Such a recent negative development imposes challenges for dam site selection that is often based on past and outdated hydrological conditions, especially concerning river discharge, without enough knowledge about groundwater conditions. Indeed, it is important to revisit the interrelationship of groundwater, surface water, and site selection under the new hydrological conditions for designing better water resource management plans.

A detailed knowledge of the geology of the dam site and the future reservoir, as well as of its catchment area, is necessary before the dam site is selected; acquiring such knowledge should be vital in the siting, design, and construction of any dam (Best, 1981). Such knowledge is critically important if the site is in a karst region because of the intimate connection between surface water and groundwater in the region and the rapid pathways or channels likely to connect the surface water in the reservoir with the nearby karst groundwater (Bonacci and Rubinić, 2009; Milanović et al., 2010; van Beynen, 2011; Kazemi, 2012).

The karst groundwater boundary may be very different from the surface catchment boundary, as the groundwater flow may be through underground conduits to discharge at springs far beyond the catchment boundary (Currens, 2002; Chen et al., 2004; Rezaei et al., 2013). In addition, the boundary of a catchment area in karst terrains may occasionally or permanently change due to both natural processes and anthropogenic interventions (Bonacci et al., 2016). Dam site selection in karst is always risky, and some inadequately investigated dams have never fully filled with water or failed to retain any water (Milanović, 2000; Dokmanovic et al., 2003; Bonacci and Rubinić, 2009; Milanović et al., 2010, van Beynen, 2011). Therefore, understanding the hydrogeological conditions, especially the recharge and discharge zones of the catchment, is essential for selecting an appropriate dam site.

\footnotetext{
* Corresponding Author: haji.karimi@gmail.com, h.karimi@ilam.ac.ir.

${ }^{1}$ Faculty of Earth Sciences, Institute for Advanced Studies in Basic Sciences (IASBS), Zanjan 45137-66731, Iran

${ }^{2}$ Center for Research in Climate Change and Global Warming (CRCC), Institute for Advanced Studies in Basic Sciences (IASBS), Zanjan 45137-66731, Iran

${ }^{3}$ Faculty of Agriculture, Ilam University, Ilam, Iran

${ }^{4}$ Department of Geology and Geophysics, Texas A\&M University, College Station, TX 77845, USA
} 
Moreover, the hydrogeological conditions may affect the water quality after the construction of the dam, depending on the lithology of the reservoir rocks. For instance, if halite and gypsum rocks exist in the reservoir site, they may dissolve rapidly after the construction of the dam and eventually change the surface and groundwater geochemistry and degrade the water quality. For instance, the total dissolved solids in evaporite formations containing halite, gypsum, or anhydrite may rise two to three hundred thousand parts per million (Clark, 2015). About 95\% of the Kangir Reservoir sits above the evaporate-rich Gachsaran Formation, dissolution of which will have a major impact on reservoir water quality. Sulfate concentrations in water usually equal $1000 \mathrm{mg} / \mathrm{l}$ in gypsum-karst terrains, making them inappropriate for domestic water supplies (Raeisi et al., 2013).

The dissolution of halite and gypsum beds at the reservoir site will increase the water leakage rates from the reservoir because dissolution of halite and gypsum is likely to augment its permeability (Calcano and Aizura, 1967; James and Lupton, 1978; James and Kirkpatrick, 1980; Warren et al., 1990; Dreybrodt et al., 2002; Kiyani et al., 2008; Al-Rawi et al., 2011). Weisbrod et al. (2012) reported that dissolution fissures may be created if the seepage rate increases above a threshold value, even in salt rocks that appears to be relatively homogeneous and without fractures.

The Gachsaran Formation, with high solubility (Aghanabati, 2004), crops out over approximately 20 thousand square kilometers in the south and southwest parts of Iran (Raeisi et al., 2013). Despite its obvious effects of degrading water quality of reservoirs and adjacent aquifers, they are sometimes overlooked in the site-selection process. As a case in point, the reservoir of the Upper Gotvand Dam in southwest of Iran, constructed on the Karun River with electrical conductivity of $500 \mu \mathrm{S} / \mathrm{cm}$, is located above halite layers of the formation where the conductivity of water increased up to $170,000 \mu \mathrm{S} /$ $\mathrm{cm}$ in the lower layers of the reservoir because of halite dissolution (Kayhan, 2015).

This study concerns the Kangir Reservoir catchment of Iran, where the construction of the Kangir Reservoir dam began in 1991 and was completed in 2013. It is an earthen dam with impervious clay core, with a $745 \mathrm{~m}$ length of the crest and $42 \mathrm{~m}$ height from the basement. The storage capacity of the Kangir Reservoir, $2.13 \mathrm{~km}^{2}$ in area, is about 20 million cubic meters (MCM). This reservoir plays an important role in supplying water to a community of 70,000 , and provides irrigation water for a cropland with an area of 2500 ha. The reason we chose the Kangir Reservoir for this study is that this reservoir was mainly designed on the basis of discharge information of the Kangir River over the past three decades, overlooking issues associated with climate change and overexploitation of water resources. At present, the Kangir River does not fill the reservoir. On the other hand, the surrounding karst groundwater was not considered as a potential source for the reservoir simply because there was not enough knowledge about the karst hydrogeology in the catchment before designing the dam. In addition, this reservoir is unique because about $95 \%$ of it is in direct contact with the marl, gypsum, and halite units in the evaporite Gachsaran Formation (Karimi and Pakzad, 2009).

The objective of this research was to find out how important the karst groundwater conditions are and how the rock types would affect the reservoir water. We employed a host of investigative tools, including water balance analysis, general flow direction, hydrochemistry, the distribution of karst and evaporite formations in the catchment, and tectonic setting to illustrate the issue from multiple angles. The final objective was to use the results of our analyses to guide future site selection in the karst terrain to meet the water-supply need and at the same time to minimize the negative water quality impact.

\section{STUdy AREA}

The study area is located $45 \mathrm{~km}$ north west of Ilam city, Iran, between $45^{\circ} 50^{\prime}$ and $46^{\circ} 27^{\prime}$ longitude and $33^{\circ} 0.68^{\prime}$ and $34^{\circ} 4^{\prime}$ latitude (Fig. 1). The site is characterized as a humid climate with $667 \mathrm{~mm}$ average annual rainfall, $12.39{ }^{\circ} \mathrm{C}$ average annual temperature, and $1783 \mathrm{~mm}$ average potential evaporation (Rezaei, 2015). The watershed of the Kangir Reservoir is surrounded by highlands of Bankul (north), Manesht (east), and Sharezol (south). The Kangir River is the main surface water inflow to the reservoir, with an average long-term discharge rate of $1.53 \mathrm{~m}^{3} \mathrm{~s}^{-1}$. Note that the average discharge rate of the river has been decreased to about 0.68 $\mathrm{m}^{3} / \mathrm{s}$ in the last five years. The water levels in the piezometers near the river at the eastern and middle parts of the Eivan Plain are higher than the riverbed, so groundwater drains into the river. However, in recent years the river has become ephemeral during summer, since its water is diverted for agricultural purposes.

The main geologic formations of the study area are the Pabdeh marl and marl limestone, the Asmari limestone, and the Gachsaran gypsum (Aghanabati, 2004), following a decreasing order of age. The Asmari Formation, the main karstic aquifer in Zagros, covers approximately $61 \%$ of the catchment, primarily in the highlands area (Fig. 2). The evaporite Gachsaran covers about $95 \%$ of the reservoir area to an average thickness around $60 \mathrm{~m}$ (Karimi and Pakzad, 2009), and it negatively affects the reservoir water quality, as it mainly contains marl, gypsum, halite, and limestone. The highly soluble gypsum and halite layers can elevate the conductivity of groundwater from 1100 up to $12000 \mu \mathrm{S} / \mathrm{cm}$ (Raeisi et al., 2013). The Pabdeh Formation usually acts as a barrier to groundwater flow in the Zagros Mountains.

\section{Method of Study}

The investigation was carried out in two phases. The first phase studied the karst hydrogeological system; the second phase examined the influence of the evaporate Gacharan Formation on the water quality of the catchment area. In 


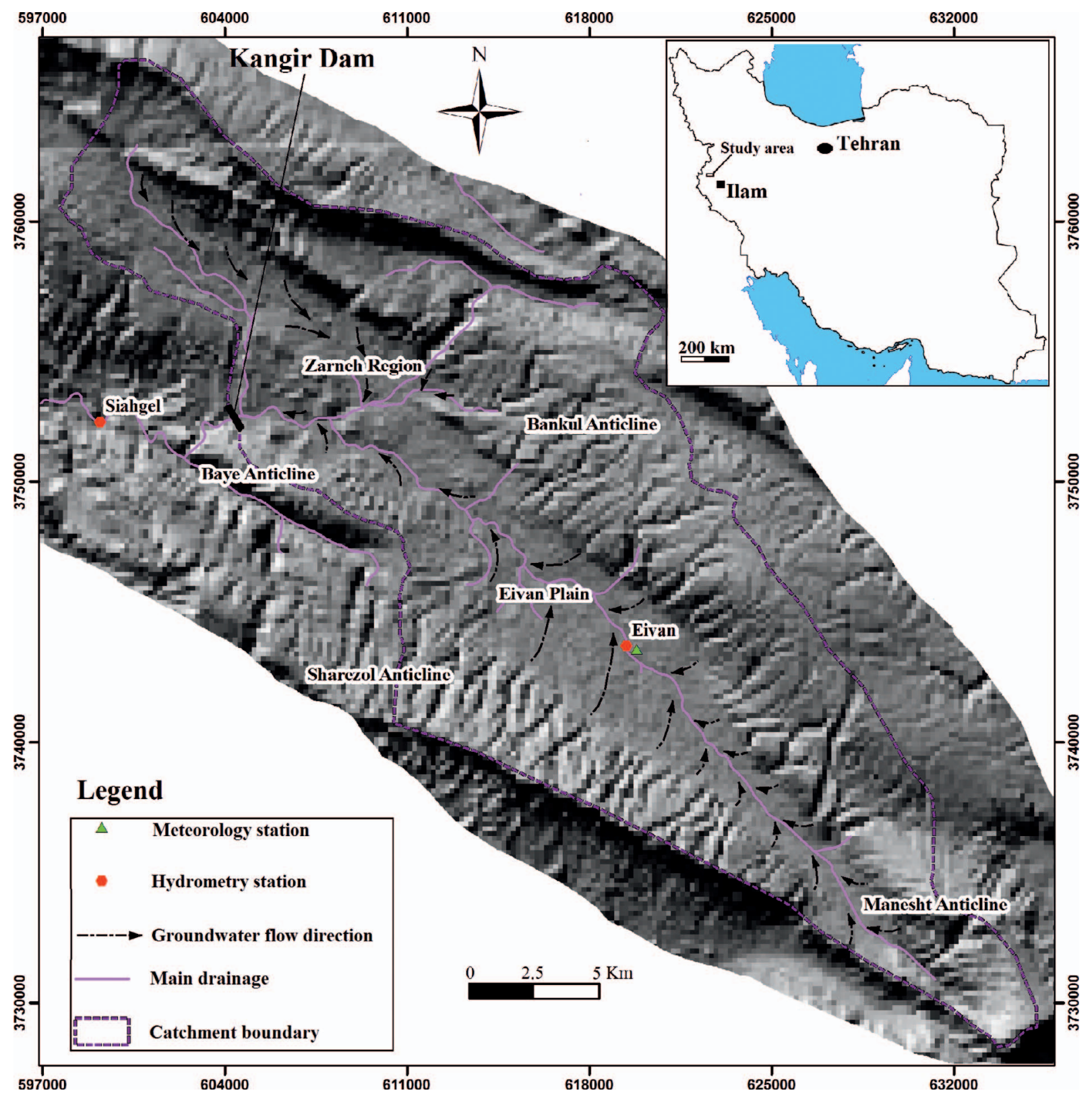

Figure 1. Location of the Kangir Dam site, the Kangir Reservoir catchment, and hydrograph stations.

addition, we predicted the impact of the GF on the quality of the reservoir water. The hydrogeological condition in the study area was studied by preparing groundwater equipotential maps, investigating the water balance, and analyzing hydrochemistry data and the tectonic setting. We acquired the discharges of springs, discharge of the Kangir River at the reservoir inlet, hydrographs at the Eivan and Siahgel hydrometric stations, and meteorological data of the study area from the Ilam Regional Water Authority (IRWA) archive. This archive contains weekly discharge data for the Kangir River at the reservoir inlet and Eivan and Siahgel hydrometric stations from January to April 2014. In addition, 15 water samples from springs, wells, and the river from the ZarnehSiahgel fault zone area were collected and analyzed in
October 2015. The discharges of the Kangir River at R2 and R3 locations in Figure 2, upstream and downstream of Sorkhejo Springs, were also measured when the Kangir River at the reservoir inlet dried up and the outlet floodgates were completely shut down. There were not enough observation wells available for preparing an adequate equipotential map, thus this map must be used with caution. We filled in the spatial gaps between the observation wells using the elevations of the static water table at production wells during the no-pumping period in the autumn and winter seasons to improve the equipotential map of the Zarneh Region as a part of the Eivan Plain. To ensure that the wells were completely recovered, we measured the water table about three months after the pumping from the aquifer was stopped. Three months 


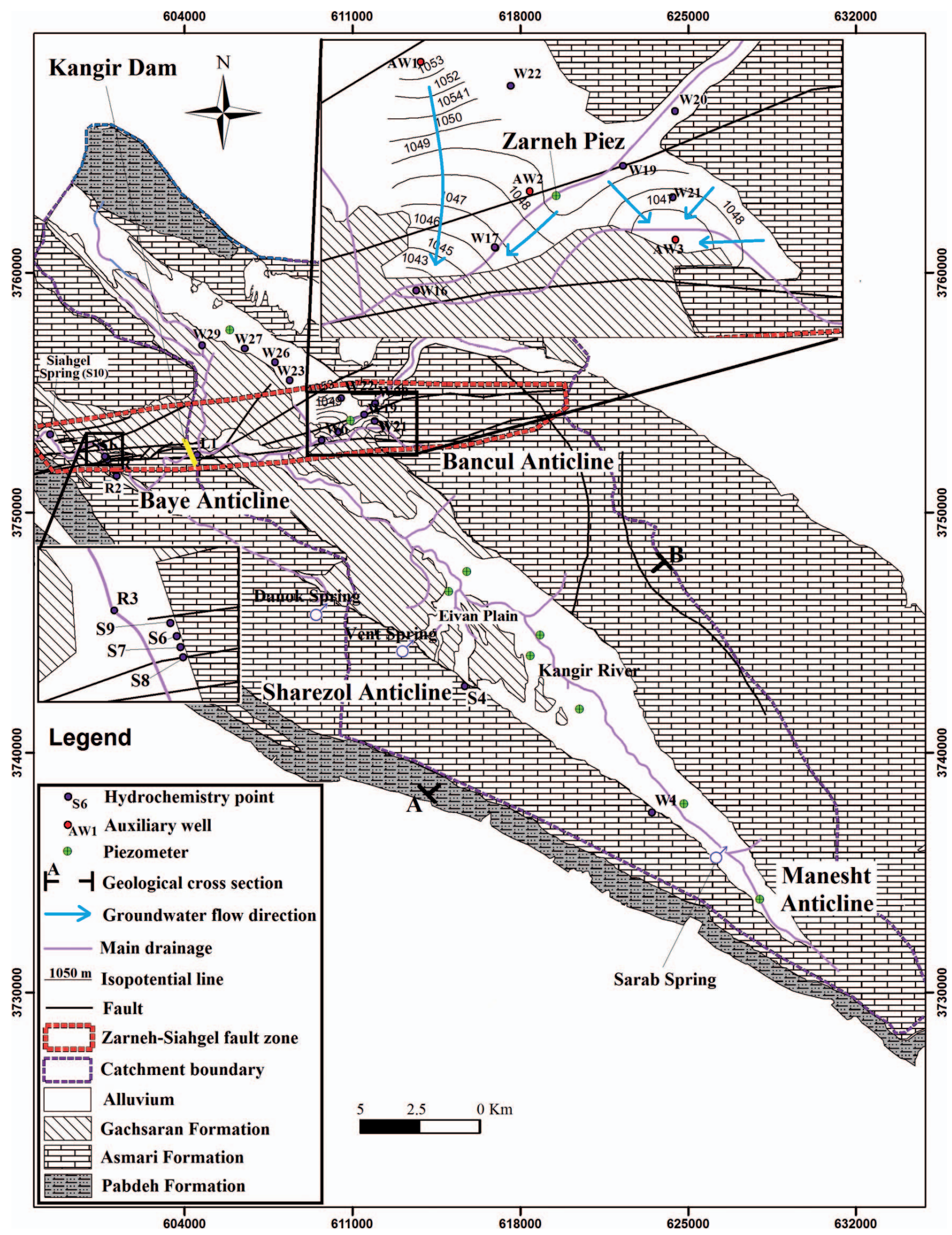

Figure 2. Hydrogeological map of the study area. Upper and lower insets show the Zarneh and Siahgel regions, respectively. AW1-AW3 are the auxiliary wells that were considered when preparing the equipotential map. The line A-B is the location of the cross-section in Figure 3. 
Table 1. Groundwater budget components in the basin.

\begin{tabular}{|c|c|c|c|c|c|c|c|}
\hline \multicolumn{3}{|c|}{ Recharge, MCM } & \multicolumn{5}{|c|}{ Discharge, MCM } \\
\hline $\begin{array}{c}\text { Recharge } \\
\text { from Rainfall }\end{array}$ & $\begin{array}{c}\text { Agricultural } \\
\text { Water Return }\end{array}$ & Total & $\begin{array}{l}\text { Production } \\
\text { Wells }\end{array}$ & Springs & $\begin{array}{c}\text { Base Flow } \\
\text { of Kangir River }\end{array}$ & $\begin{array}{c}\text { Missing } \\
\text { Groundwater }\end{array}$ & Total \\
\hline 112 & 1.5 & 113.5 & 9 & 28 & 27 & $49.5 \pm 21$ & 113.5 \\
\hline
\end{tabular}

seems to be reasonable time since (1) the alluvium in the Zarneh Region contains coarse-grain soil according to the lithological log of the piezometers; (2) the water table rapidly responds to the recharge of precipitation since the time lag is about 1 to 2 months (Rezaei, 2015), and (3) the total pumping from the aquifer is not much in the summer. The production wells we selected were in the same aquifer as the observation wells to ensure data consistency since (1) the alluvial aquifer in the Zarneh Region is a one-layer unconfined aquifer (Rezaei, 2015); (2) the Zarneh piezometer is located somewhere between the production wells that were used to measure the water table and they have the same depth, and (3) no screens were installed in the production wells, while the screen in the piezometer is installed over the depth from the water table to the bottom.

To understand the influence of the evaporite minerals in the GF on water quality, we prepared zoning maps of electrical conductivity and sulfate and calcium ions in the Eivan Plain, as well as bivariate graphs of EC-sulfate and sulfate-calcium using the available hydrochemistry samples held by the IRWA archive for the period from 2006 to 2010. We also collected water samples in October 2015 (Table S1, presented in Supplementary Information).

The water samples were collected in clean plastic bottles and were immediately sent to the Geochemistry Lab of NovinRahavard, Zanjan, Iran. The water temperature, EC (by Lovibond Conductivity meter, SensoDirect Con 110) and $\mathrm{pH}$ (by Lovibond pH meter, SensoDirect pH 110) were measured in the field during sampling. Calcium and magnesium concentrations were determined using titration with EDTA (Eriochrom Black-T and Murexide as indicators). Sodium and potassium concentrations were estimated by flame photometry methods. Sulfate and nitrate concentrations were determined by spectrometry methods. Bicarbonate and chloride were measured using titration with $\mathrm{H}_{2} \mathrm{SO}_{4}$ (Methyl orange as indicator) and silver nitrate (potassium chromate as indicator), respectively.

\section{Groundwater Balance of the Kangir Reservoir CAtchment}

The long-term water budget of the Kangir Reservoir catchment from 1976 to 2011 reveals that about 112 MCM of total precipitation (293 MCM) recharged the groundwater, while the evapotranspiration and runoff were 160 and 21 MCM, respectively (Rezaei, 2015). These were climatologically estimated using observations like daily precipitation, temperature, evaporation, wind speed, and relative moisture of air, along with monthly discharge values of the Kangir River. Accordingly, the estimation of a long-term water budget of groundwater in the catchment indicated that about $49 \mathrm{MCM}$ of groundwater drained into the surrounding regions (Table 1). This value was obtained using the long-term components of recharge and discharge in the catchment, which the average error may be associated with it $\left(e_{\mathrm{mg}}\right)$ was estimated to be about $43 \%$ (ranges from 23 to 63); that is, about 21.9 (ranges from 11.2 to 30.7$) \mathrm{MCM}$. One can calculate the error using (Winter 1981) $e_{\mathrm{mg}}=e_{\mathrm{rr}}+e_{\mathrm{awr}}+e_{\mathrm{pw}}+e_{\mathrm{s}}+e_{\mathrm{bf}}$, where $e_{\mathrm{rr}}$ and $e_{\text {awr }}$ are the error in the recharge from rainfall and the agricultural water return flow, respectively. Terms $e_{\mathrm{pw}}, e_{\mathrm{s}}$, and $e_{\mathrm{bf}}$ represent the error in the groundwater pumping of production wells, spring discharge, and the base flow of the Kangir River, respectively. The main recharge components of the groundwater system are recharge from precipitation (112 MCM) and agricultural water return flow (1.5 MCM). The main discharge components include groundwater pumping (9 MCM), spring discharge (28 MCM), and the base flow of the Kangir River (27 MCM). For practical purpose, we considered the error of 12.5 (ranges from 5 to 20) percent in the long-term groundwater recharge estimated by Rezaei (2015) in the area (Mohammadi et al., 2014). Agricultural return flow is considered to be 20 percent of the total used water with a reasonable error of 5 percent according to the range values applied in different plains of Iran (Alipour Shams-Abad, 1998; TECC, 2010; Hosseini et al., 2010; Mohammadi et al., 2014). The groundwater pumping data and springs' discharges were extracted from the archive of the IRWA. The estimation of the error associated with the groundwater pumping data in Iran is impossible, as there were no permanent flow meters on production wells and the data were only collected for a few years. From a practical point of view, we considered a 10 percent error in the withdrawal groundwater from production wells. We also considered an error of 5 percent associated with the springs discharge measurements (Kjelstrom, 1995).

The straight-line method (Chow et al., 1988) was used to determine the long-term base flow of the Kangir River at the reservoir inlet. In the absence of long-term discharge observation at the reservoir inlet, we used the relationship between the weekly discharges values at the reservoir inlet and those of the Eivan and Siahgel hydrometric stations to meet the need. This is possible because the discharge at the reservoir inlet is nearly equivalent to the average discharge of the Siahgel and Eivan stations; as can be seen on Fig. S1 (presented in Supplementary Information). Consequently, the 


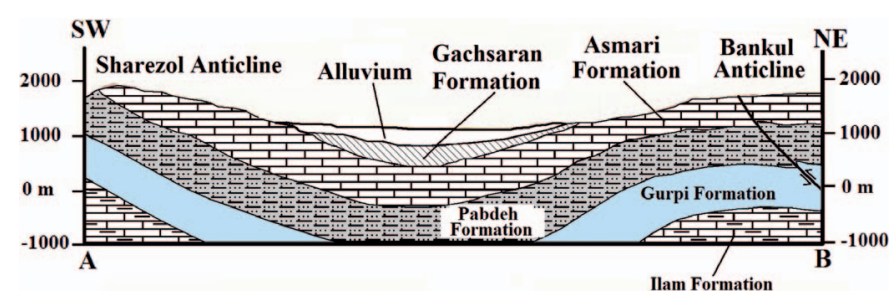

Figure 3. Schematic geological profile across the Eivan Plain; the location is shown on Figure. 2).

long-term discharge at the reservoir inlet was taken as the long-term average discharge of the Siahgel and Eivan stations. Note that because the components used in the long-term groundwater budget were average values, we were unable to calculate the long-term change in the reservoir water volume. We also considered a 17 percent error associated with the base flow estimation according to the error ranging from 12 to 22 percent (Santhi et al., 2008).

\section{Deficit in Groundwater Budget}

As mentioned above, there is a $49.5 \pm 21 \mathrm{MCM}$ groundwater deficit for the Kangir Reservoir catchment. None of this "missing" groundwater can rise into the northern plain of the Bankul Anticline, with an elevation of $1300 \mathrm{~m}$ above mean sea level, or the eastern plain of Manesht Anticline, with an elevation of $1335 \mathrm{~m}$, as they are much higher than the Eivan Plain at $1070 \mathrm{~m}$. In addition, the geological cross section (Fig. 3) shows that the low-permeability Pabdeh Formation in both anticlines lies structurally above the Asmari Formation contact with the alluvium of Eivan Plain. Among the surrounding regions, the southern plain of Sharezol Anticline and Siahgel Region have lower elevations (1000 $\mathrm{m}$ and $890 \mathrm{~m}$, respectively) than the Eivan Plain, so these locations might receive the missing groundwater.

The Asmari Formation is completely missing from the southern limb of the Sharezol Anticline as outlined near the Aend in Figure 3. In addition, the geological cross section indicates that the low-permeability Pabdeh Formation crops out at a higher elevation $(1600 \mathrm{~m})$ than the Asmari Formation contact with the Eivan Plain alluvium $(1208 \mathrm{~m})$. This geometry prevents any water draining from the Eivan Plain to the southern plain of the Sharezol Anticline. Consequently, the "missing" groundwater is unlikely to end up there. Therefore, the Siahgel Region is the most likely destination of the groundwater. To test this hypothesis, the hydraulic relationship between the groundwater of the Sharezol, Baye, and Bankoul anticlines and the Siahgel Region was investigated.

Sharezol Anticline: The hydraulic relationship between the Sharezol Anticline and the Eivan Plain alluvium, from the location of Khoran Spring (S4 in Fig. 2) toward the Siahgel Region, is blocked by the low-permeability Gacharan Formation. However, along the anticline axes toward the

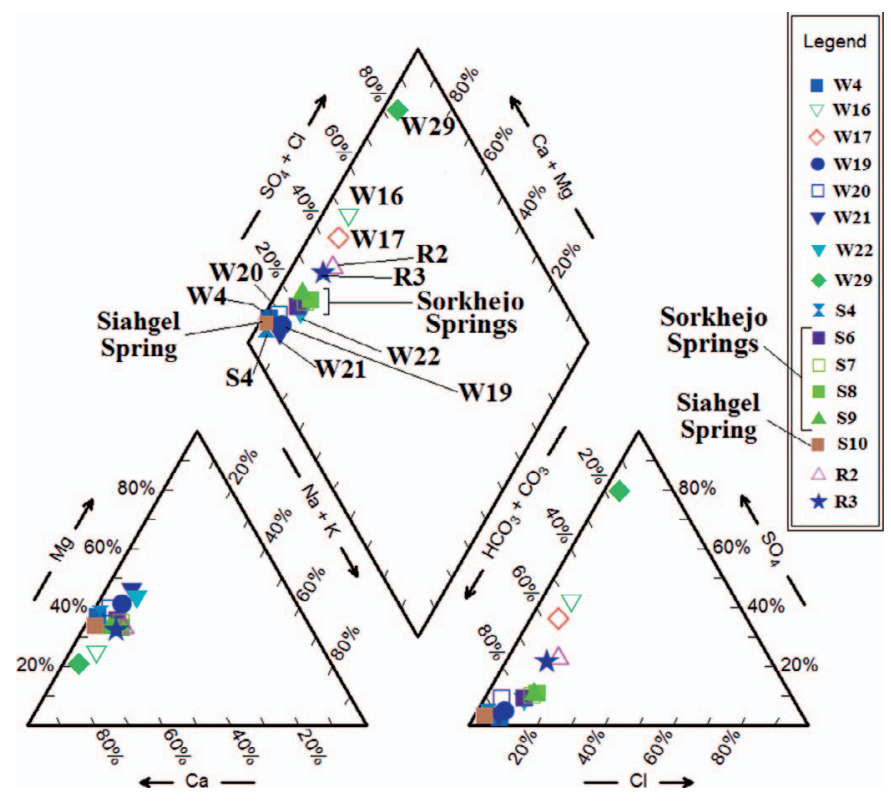

Figure 4. The Piper Diagram for the water samples of October 2015. Spring locations are shown in Figure 2.

northwest, the karstic Asmari Formation of the Sharezol Anticline is in direct contact with the Siahgel Region and has the lowest topographic elevation in the area. Furthermore, the water sample from the Siahgel Spring (presented in Fig. 2) on the Piper plot shows similar geochemical characteristics to the Khoran Spring (S4 in Fig. 4), suggesting that they may share the same source.

This hypothesis is also confirmed by our water budget calculation for the Sharezol Anticline. The Asmari Formation cropping out in that part of the Sharezol Anticline that falls within the dam catchment has an area of $65 \mathrm{~km}^{2}$, and this area is annually recharged by about $23.6 \mathrm{MCM}$ of groundwater because the recharge coefficient in this area is estimated to be about 0.5 (Rahnemaaie, 1994; Pezeshkpour, 1991; Karimi et al., 2001; Karimi et al., 2005; Ashjari and Raeisi, 2006; Kalantari et al., 2016) and the annual precipitation is $726 \mathrm{~mm}$. The total discharge from karstic springs (Khoran (S4), Vent, Danok and Sarab Springs shown in Fig. 2) in this area is about 18.54 MCM. Hence, when considering the water budget estimation error $(10 \%)$ associated with the karstic terrains of the Zagros Mountains (Ashjari and Raeisi, 2006), it seems that the total water produced in the Asmari Formation within the catchment discharges from the karstic springs of Khoran, Vent, Danok, and Sarab. But the groundwater produced by the rest of the Asmari Formation in the Sharezol Anticline is distributed out of the catchment and finally discharges into the Kangir River near the outlet of the Siahgel Region.

Baye and Bankul Anticlines: The groundwater that escapes from the Kangir Reservoir catchment drains mainly to the Sorkhejo Springs (i.e. S6 to S9) and the Kangir River along the Zarneh-Siahgel fault zone in the Siahgel Region (Fig. 2). To support this claim, we provide the following evidence. 
First, there are no other springs in the Zarneh Region (upper inset in Fig. 2) structurally beneath the southern limb of the Bankul Anticline. In other words, the base level of erosion of the anticline is presumably at a lower elevation than that in the Zarneh Region and the Eivan Plain. Second, the fault zone of Zarneh-Siahgel (Fig. 2) extends from the Bankul Anticline toward the Siahgel Region. Furthermore, the groundwater level at the east end of the fault zone in the Zarneh Region has a depression cone around wells W19, W21, and AW3 (upper inset in Fig. 2); therefore, it appears that the fault zone transmits groundwater. Third, the minimum elevation of the Asmari Formation in the Baye Anticline is in direct contact with the Kangir River. This situation can easily allow the groundwater of the Baye Anticline to drain into the river as the discharge of the Kangir River increases along the Baye Anticline at the west end of the Zarneh-Siahgel fault zone (Fig. 2); the river drains the groundwater from the Baye Anticline. As a case in point, in September 2015 the river dried up just downstream of the dam, while its discharge gradually increased towards the Sorkhejo Springs. Its discharge finally reached $650 \mathrm{~L} \mathrm{~s}^{-1}$ downstream of the springs. Fourth, the water samples from the Sorkhejo Springs (S6 to S9) on the Piper diagram (Fig. 4) reflect similar geochemical features as those from wells W19 to W22 (see Fig. 2), located at the east end of the fault zone in the Zarneh Region.

Karimi and Pakzad (2009) reported that dye injected into the northern margin of the Kangir Reservoir emerged $4 \mathrm{~km}$ downstream of the dam at springs that have since dried up due to successive droughts. Furthermore, the drilling records of boreholes around the reservoir suggest that there are two different water levels in two separate aquifers in the Gachsaran and Asmari Formations, and the water level in the Asmari Formation is much lower than that in the Gachsaran (Karimi and Pakzad, 2009). Consequently, most of the karst water produced in the catchment, especially in the Bankul Anticline, does not enter the reservoir. Instead, it drains to the Sorkhejo Springs and the Kangir River in the Siahgel Region along the Zarneh-Siahgel fault zone that intercepts the Asmari Formation beneath the Gachsaran Formation. A precise calculation of the water leaking from the Bankul Anticline into the Siahgel Region is not possible; this is because an unknown amount of groundwater from the Bankul Anticline recharges the Eivan Plain, where the piezometric network is not dense enough to construct an accurate enough equipotential map to calculate the flow under the Eivan Plain.

\section{HYDROCHEMISTRY}

We used the water samples collected on October 2015 to test the "missing" water hypothesis outlined above. Then the impact of the Gachsaran Formation on water quality in the Kangir Reservoir and the Eivan Plain was investigated using not only all the available data in the IRWA archive for 2006 to
2010, but also water samples collected in October 2015. According to the water samples of October 2015 presented in the Piper plot (Fig. 4), water samples taken from wells near the Zarneh Piezometer have a conductivity range from 394 to $553 \mu \mathrm{S} \mathrm{cm}$ (W19 to W21). These exhibit geochemical features similar to the Sorkhejo Springs water samples (S6 to S90) that range from 671 to $745 \mu \mathrm{S} \mathrm{cm}^{-1}$. A point to note is that the values of the Sorkhejo Springs are slightly higher than those of the wells. This is probably due to the effect of the Gachsaran Formation yielding higher EC values for wells penetrating it, for instance an EC value of $2450 \mu \mathrm{S} \mathrm{cm}$ for water sample fromW29.

Interestingly, as can be seen in Fig. 2, the spatial distribution of wells W19 to W21 and the Sorkhejo Springs spreads around the fault zone, suggesting that the fault zone might provide a pathway for the groundwater drained from the Bankul Anticline and the Zarneh Region towards the Sorkhejo Springs in the Siahgel Region, downstream from the dam. In addition, the locations of the Kangir River water samples with conductivity of about $705 \mu \mathrm{S} \mathrm{cm}^{-1}$ (R2 and R3, upstream and downstream of the Sorkhejo Springs, respectively) on the Piper plot are the same as those from the Sorkhejo Springs.

A notable issue is that the nitrate concentration in W20 (7.19 $\mathrm{mg} \mathrm{L}^{-1}$ ), measured on the southern limb of the Bankul Anticline at the east end of the Zarneh-Siahgel fault zone, lies within the range of nitrate concentrations values measured for water samples from the Sorkhejo Springs (about 6.09 to 9.26 $\mathrm{mg} \mathrm{L}^{-1}$ ). This evidence confirms the hypothesis that the Sorkhejo Springs drains most of the karst groundwater in the Bankul Anticline.

Another notable geochemical issue is that most of the Kangir Reservoir is in direct contact with the evaporite-rich Gachsaran Formation. Investigation of the zoning maps of EC, calcium, and sulfate (Figs. 5 a-c) along with the Piper diagram in Figure 6 indicates that the evaporate-rich GF degrades the water quality of the karstic Asmari Formation in several ways. First, it increases the values of conductivity, sulfate, and calcium (Fig. 5). Second, it converts the bicarbonate water type of the karstic Asmari Formation into sulfate and chloride water as outlined in Fig. 6. The water samples collected from the karstic Asmari Formation exhibit low conductivity and bicarbonate water type; for example, water samples from W3W5, W7, W11, S4, and S5 on the northern limb of the Sharezol Anticline have EC of 427 to $587 \mu \mathrm{S} \mathrm{cm}$, and those from W19-W22 on the southern limb of the Bankul Anticline in the Zarneh Region have EC of 394 to $553 \mu \mathrm{S} \mathrm{cm}^{-1}$.

Consistent with the Gachsaran Formation distribution over the area, the highest groundwater EC value is found in the reservoir (M4 with chloride water type); this almost certainly arises from the dissolution of gypsum and salty layers in the GF. Water samples from W29 with an EC value of $2450 \mu \mathrm{S} /$ $\mathrm{cm}$ and M3 with an EC value of $2412 \mu \mathrm{S} \mathrm{cm} \mathrm{cm}^{-1}$ are characterized as sulfate-water type. This is because both are strongly affected by the dissolution of the GF (Fig. 5). The rest of the water samples lie somewhere between these two water categories of the Asmari Formation and the GF on the Piper 

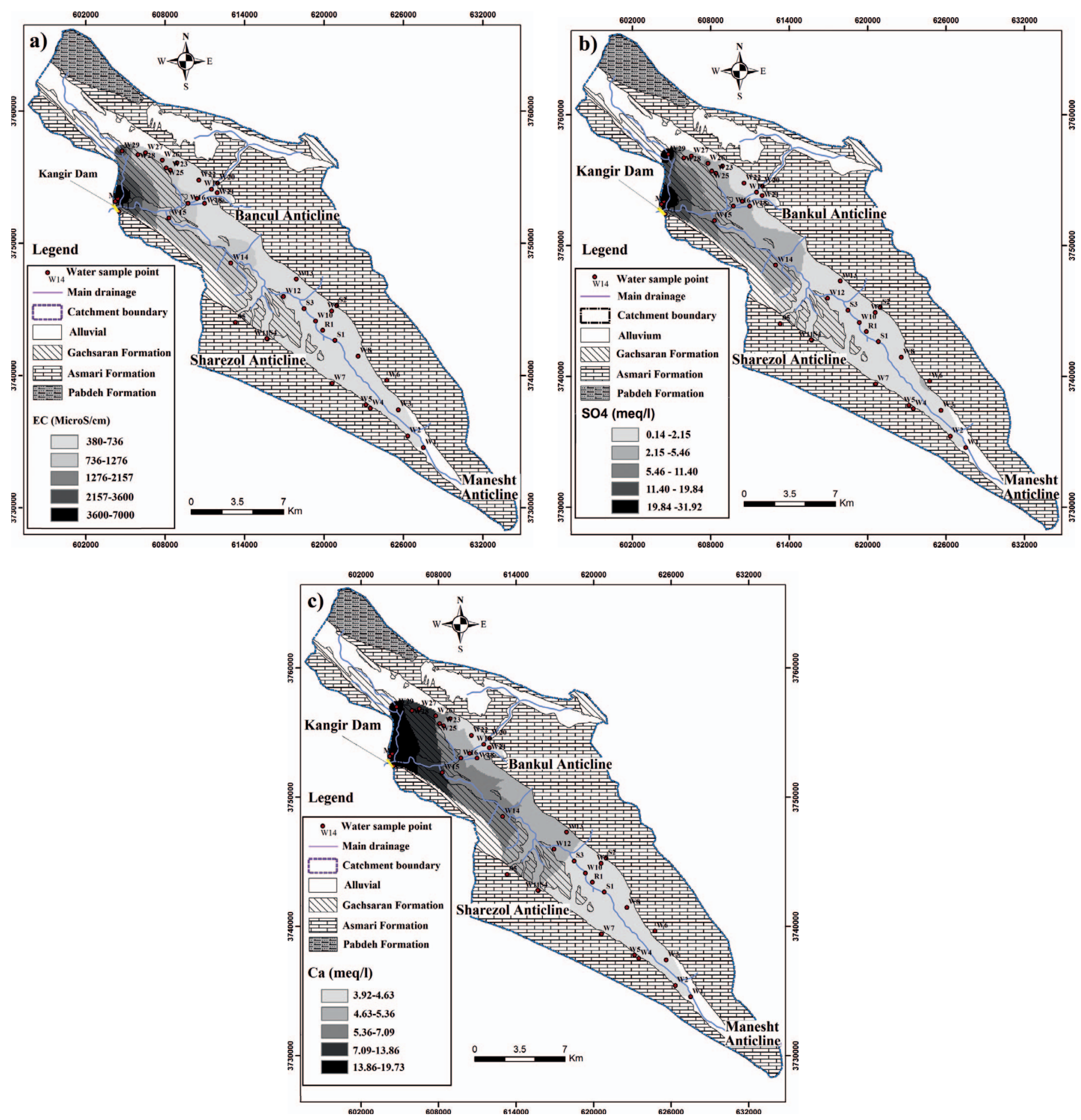

Figure 5. The zoning maps of (a) electrical conductivity, (b) sulfate, and (c) calcium cation in the Eivan Plain.

plot (Fig. 6). In general, the values of EC, chloride, sulfate, and calcium rise towards the dam, and the bicarbonate water type changes to the sulfate water type (Fig. 5).

It appears that increasing the reservoir water level further reduces the reservoir's water quality, probably because the relative contact area of the reservoir water with the GF increases. For instance, we conducted one experiment by pouring $100 \mathrm{ml}$ of distilled water onto a $100 \mathrm{gr}$ soil sample taken from the gypsum on the base of the reservoir. The EC value rose to $1450 \mu \mathrm{S} \mathrm{cm} \mathrm{cm}^{-1}$ almost instantaneously and to $1950 \mu \mathrm{S} / \mathrm{cm}$ after two months.

Taking the above mentioned points into consideration, the Kangir Reservoir site is undesirable from a geochemical perspective. One must be aware that farmlands irrigated using 


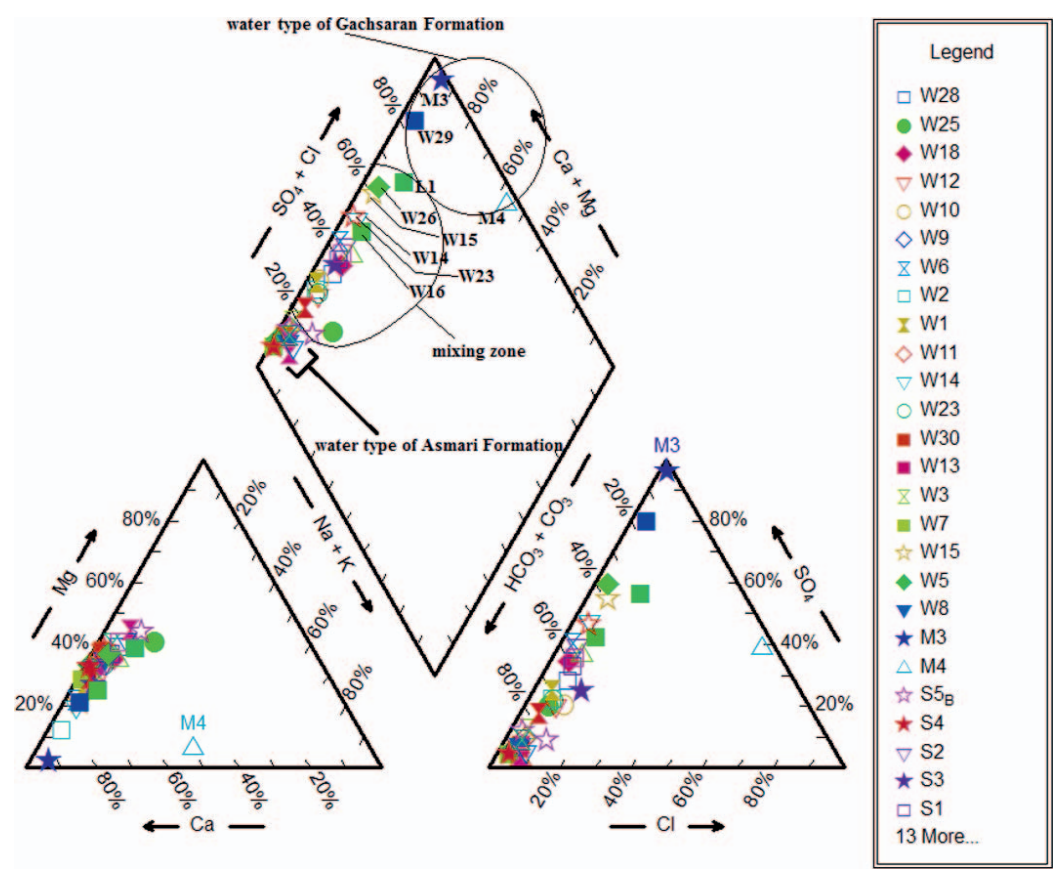

Figure 6. Piper Diagram of the water samples from the Eivan Plain. Sample locations are shown in Figure 5.

such a degraded Kangir Reservoir water can decrease agricultural productivity through a slow process of salinization and chemical deterioration of soil, and it will degrade the fresh-water resources in the area by leaking the degraded reservoir water into the relatively unpolluted groundwater and surface water.

Investigation of the bivariate curves of conductivity-sulfate and sulfate-calcium indicates that these three parameters have a linear relationship with each other (Fig. 7). This signifies that the water quality in the reservoir catchment increasingly degrades with increasing concentrations of sulfate and calcium from dissolution of gypsum in the Gachsaran Formation. As shown in Figure 7, the water samples in the GF (e.g., M4, W29, M3, W26, W15, W14, W16, and L1) represent the highest values not only for $\mathrm{EC}$, but also for sulfate and calcium. As a case in point, water sample L1 (EC $=885 \mu \mathrm{S} \mathrm{cm}{ }^{-1}$ ) taken directly from the reservoir, clearly shows that the high quality of the Kangir River, characterized by the long-term average EC of $564 \mu \mathrm{S} \mathrm{cm}^{-1}$ and bicarbonate water type at the Eivan Station, will no longer exist after entering the Kangir Reservoir behind the Kangir dam. It is worth pointing out that the L1 sample with its sulfate water type was collected when the water level of the Kangir Reservoir was almost in direct contact with the river alluvium. The degradation is likely to worsen as the reservoir water level rises and widens contact with the GF.

\section{CONCLUSION}

A large portion of the Kangir Reservoir catchment's groundwater drains out of the catchment and into the surrounding regions through subsurface pathways. The higher elevation of the low-permeability Pabdeh Formation in the Bankul, Manesht, and Sharezol anticlines prevents hydraulic connection between the reservoir catchment to the surrounding plains in the north, east, and south. Groundwater escapes from the Kangir Reservoir catchment into the Siahgel Region and the Sorkhejo Springs downstream of the Kangir dam through the Zarneh-Siahgel fault zone. The evaporite minerals in the Gachsaran Formation that underlie most of the Kangir Reservoir have a negative influence on water quality in the Kangir Reservoir catchment; the highest values of conductivity, sulfate, calcium, and chloride are found in and near the reservoir itself. The Kangir dam is poorly sited in the sense that the dam can collect only a small portion (about one quarter) of all the groundwater within its catchment, and the reservoir is in direct contact with the evaporite-rich Gachsaran Formation. This factor degrades water quality in the catchment. The dam may be unstable as its foundation is on the Zarneh-Siahgel fault zone. Finally, this study indicates that hydrogeological and hydrogeochemical knowledge plays a very important role in selecting and designing the reservoir and dam sites, especially in karstic areas.

\section{ACKNOWLEDGMENT}

The authors thank the Vice Chancellor for Research at the Institute of Advanced Studies in Basic Sciences (IASBS) for supporting this hydro-geochemical analysis. We are grateful to Ilam Regional Water Authority for providing the hydrologic and hydrogeological data used in this study. The 

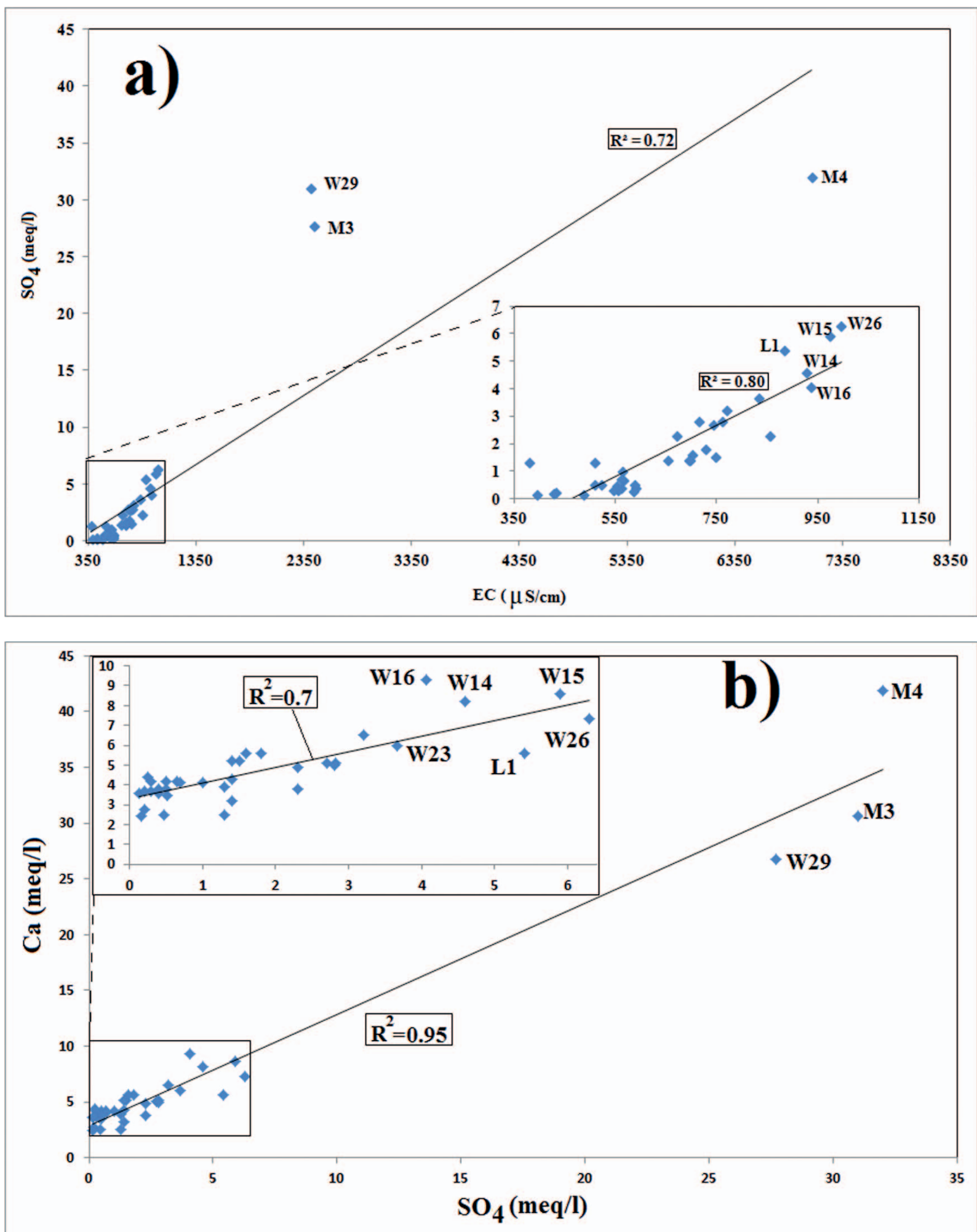

Figure 7. Bivariate graphs of (a) EC-sulfate and (b) sulfate-calcium on the Eivan Plain. Locations of labeled samples are shown in Figure 5. 
constructive comments from the editor, associate editor, and the three anonymous reviewers are deeply appreciated.

\section{REFERENCES}

Aghanabati, A., 2004, Geology of Iran: Ministry of Industry and Mines, Geological Survey of Iran, (in Farsi) 576 p.

Alipour Shams-Abad, M., 1998, Evaluation of return water of irrigation to groundwater in Kavar plain by groundwater mathematical model [Ms. Thesis]: Shiraz, University of Shiraz, (in Farsi) 112 p.

Al-Rawi, O., Ghannam, Sh., and Al-Ani, H.R., 2011, Dissolution of gypseous rocks under different circumstances: Jordan Journal of Civil Engineering, v. 5 , no. 3 , p. $357-379$.

Ashjari, J., and Raeisi, E., 2006, Influences of anticlinal structure on regional flow, Zagros, Iran: Journal of Cave and Karst Studies, v. 68, no. 3, p. 118 129.

Best, E.J., 1981, The influence of geology on the location, design and construction of water supply dams in the Canberra area: BMR Journal of Australian Geology \& Geophysics, v. 6, p. 161-179.

Bonacci, O., Buzjak, N., and Roje-Bonacci, T., 2016, Changes in hydrological regime caused by human intervention in karst: the case of the Rumin Springs: Hydrological Sciences Journal, v. 61, no. 13, p. 2387-2398. https://doi.org/10.1080/02626667.2015.1111518.

Bonacci, O., and Rubinić, J., 2009, Water losses from a reservoir built in karst the example of the Boljunčica reservoir (Istria, Croatia): Environmental Geology, v. 58, no. 2, p. 339-345. https://doi.org/10.1007/ s00254-008-1599-z.

Calcano, C.E., and Aizura, P.R., 1967, Problems of dissolution of Gypsum in some dam sites: Bull. Venezuelan Soc. of Soil Mechanics and Foundation Engineering.

Chen, Jian Sheng, Li, Ling, Wang, Ji Yang, Barry, D.A., Sheng, Xue Fen, Gu, Wei Zu, Zhao, Xia, and Chen, Liang, 2004, Groundwater maintains dune landscape: Nature, v.432, no. 7016, p. 459-460. https://doi.org/10.1038/ 432459a.

Chow, Ven Te, Maidment, D.R., and Mays, L.W., 1988, Applied Hydrology: McGraw-Hill, Water Resources and Environmental Engineering Series, $572 \mathrm{p}$.

Clark, I., 2015, Groundwater Geochemistry and Isotopes: Boca Raton, CRC Press, Taylor \& Francis Group, 456 p.

Currens, J.C., 2002, Kentucky is Karst Country! What You Should Know about Sinkholes and Springs: Lexington, Kentucky Geological Survey, Series 12, Information Circular 4, 29 p.

Dokmanovic, P., Jemcov, J., Milanović, S., and Hajdin, B., 2003, Hydrogeological risk factors of dam and reservoir construction - a case example "Bogovina": RMZ- Materials and Geoenvironment, v. 50, no. 1, p. 105 108.

Dreybrodt, W., Romanov, D., and Gabrovsek, F., 2002. Karstification below dam sites: a model of increasing leakage from reservoirs: Environmental Geology, v. 42, p. 518-524. https://doi.org/10.1007/s00254-001-0514-7.

Hosseini, A., Najafi, B., and Sadeghifar, A., 2010, Water resources balance in Feizabad-Mahvalat watershed: Basic Studies Office, Khorasan Regional Water Authority, 134 p. (in Farsi).

James, A.N., and Kirkpatrick, I.M., 1980, Design of foundations of dams containing soluble rocks and soils: Quaternary Journal of Engineering Geology and Hydrogeology, v. 13, p. 189-198. https://doi.org/10.1144/ GSL.QJEG.1980.013.03.05.

James, A.N., and Lupton, A.R.R., 1978, Gypsum and anhydrite in foundations of hydraulic structures: Géotechnique, v. 28, no. 3, p. 249-272. doi: 10. 1680/geot.1978.28.3.249.

Kalantari, N., Charchi, A., Mohammadi-Behzad, H.R., and Nadri, A., 2016, Bibitalkhone and Gariveh Springs paradox symbol of the Pabdeh karstic anticline in southwest Iran: Arabian Journal of Geosciences, v. 9, no. 2, p. 152-159. https://doi.org/10.1007/s12517-015-2153-4.

Karimi, H., and Pakzad, A.A., 2009, Water tightness evaluation of the Kangir dam reservoir, Ilam Province: Iran ICWR 2009 International Conference, Shahrood, Iran.
Karimi, H., Raeisi, E., and Zare, M., 2001, Determination of catchment area of aquifer bearing Tangab dam site using water balance method: Proceedings of the Second National Conference on Engineering Geology and the Environment, Tehran, 16-18 Oct 2001, v. 2, p. 755-773.

Karimi, H., Raeisi, E., and Zare, M., 2005, Physicochemical time series of karst springs as a tool to differentiate the source of spring water: Carbonates and Evaporites, v .20, no. 2, p. 138-147. https://doi.org/10. 1007/BF03175457.

Kayhan Newspaper, 2015, Gotvand Dam, brine factory building (report from near and far): Tehran, Iran, http://kayhan.ir/fa/news/11429. (in Farsi)

Kazemi, Gh. A., ed., 2012, Hydrogeology - A Global Perspective: Rijeka, Croatia, InTech, 232 p. https://doi.org/10.5772/1523.

Kiyani, M., Sadrekarimi, J., and Fakhri, B., 2008, Gypsum dissolution effects on the performance of a large dam: International Journal of Engineering Transactions B: Applications, v. 21, no. 2, p. 143-150.

Kjelstrom, L.C., 1995, Methods to estimate annual mean spring discharge to the Snake River between Milner Dam and King Hill, Idaho: Boise, Idaho, U.S. Geological Survey Water-Resource Investigations Report 95-4055, 9 p.

Lehane, S., 2014, The Iranian Water Crisis: Dalkeith, Australia, Future Directions International, $11 \mathrm{p}$

Milanović, P.T., 2000, Geological Engineering in Karst: Belgrade, Zebra Publishing, $347 \mathrm{p}$.

Milanović, S., Stevanovic, Z., and Jemcov, I., 2010, Water losses risk assessment: an example from Carpathian karst: Environmental Earth Sciences, v. 60, p. 817-827. doi: 10.1007/s12665-009-0219-x.

Mohammadi, Z., Salimi, M., and Faghih, A., 2014, Assessment of groundwater recharge in a semi-arid groundwater system using water balance equation, southern Iran: Journal of African Earth Sciences, v. 95, p. 1-8. https://doi.org/10.1016/j.jafrearsci.2014.02.006.

Motagh, M., Walter, T.R., Sharifi, M.A., Fielding, E., Schenk, A., Anderssohn, J., and Zschau, J., 2008, Land subsidence in Iran caused by widespread water reservoir overexploitation: Geophysical Research Letters, v. 35, no. 16, L16403. https://doi.org/10.1029/2008GL033814.

Pezeshkpour, P., 1991, Hydrogeological and hydrochemical evaluation of Kuh-e Gar-Barm-Firooz springs [Ms. thesis]: Shiraz, University of Shiraz. (in Farsi).

Raeisi, E., Zare, M., and Aghdam, J.A., 2013, Hydrogeology of gypsum formations in Iran: Journal of Cave and Karst Studies, v. 75, no. 1, p. 68 80. https://doi.org/10.4311/2011ES0234.

Rahnemaaie, M., 1994, Evaluation of infiltration and runoff in the karstified carbonatic rocks [Ms. thesis]: Shiraz, University of Shiraz, (in Farsi).

Rezaei, A., 2015, Investigation of decreasing trend of Kangir river discharge into Kangir dam reservoir, Ilam: Report for Research Activity of Military Service Period, Water Authority of Ilam, (in Farsi) 112 p.

Rezaei, A., Zare, M., Raeisi, E., and Ghanbari, R.N., 2013, Interaction of a freshwater lake and a karstic spring via a syncline fold: Groundwater, v. 51, p. 305-312. https://doi.org/10.1111/j.1745-6584.2012.00977.x.

Santhi, C., Allen, P. M., Muttiah, R.S., Arnold, J.G., and Tuppad, P., 2008, Regional estimation of base flow for the conterminous United States by hydrologic landscape regions: Journal of Hydrology, v. 351, no. 1, p. 139153. https://doi.org/10.1016/j.jhydrol.2007.12.018.

TECC, 2010, Upgrading the modulation studies of water resources of Qaraqum watershed: Kalat Naderi studying region: v. 3, appendix 2, $44 \mathrm{p}$. (in Farsi).

van Beynen, Ph.E., ed., 2011, Karst Management: Dortrecht, Springer, 489 p https://doi.org/10.1007/978-94-007-1207-2.

Warren, J.K., Havholm, K.G., Rowen, M.R., and Parsley, M., 1990, Evolution of gypsum karst formation in the Kirschberg Evaporite near Fredericksburg, Texas: Journal of Sedimentary Petrology, v. 60, p. 721-734. https:// doi.org/10.1306/212F925A-2B24-11D7-8648000102C1865D.

Weisbrod, W., Alon-Mordish, C., Konen, E., and Yechieli, Y., 2012, Dynamic dissolution of halite rock during flow of dilute saline solutions: Geophysical Research Letters, v. 39, L09404, https://doi.org/10.1029/ 2012 GL051306.

Winter, T.C., 1981, Uncertainties in estimation the water balance of lakes, Water Resources Bulletin, v. 17, no. 1, p. 82-115. https://doi.org/10.1111/ j.1752-1688.1981.tb02593.x. 